\title{
A Karyological Study in Some Species of Coffea L. and in the Closest Relative Psilanthus travancorensis (Wight \& Arn.) J.-F. Leroy
}

\author{
Neiva Izabel PIEROZZI', Thalita C. BORGHI ${ }^{2}$, Maria Bernadete SILVAROLLA ${ }^{3}$ \\ ${ }^{1}$ Instituto Agronômico de Campinas (IAC), CPD Recursos Genéticos Vegetais, 1481 Barão \\ de ItapuraAv., Campinas, 13020-902,Brazil; pierozzi@iac.sp.gov.br \\ ${ }^{2}$ Trainee at Laboratorio de Citogenética Vegetal, IAC, Brazil \\ ${ }^{3}$ Instituto Agronômico de Campinas (IAC), Centro de Café "Alcides Carvalho", 1481 Barão de Itapura Av., Campinas, 13020-902, Brazil
}

\begin{abstract}
Chromosome characterization were carried out in Coffea kapakata A. Chev (Bridson), C. racemosa Lour., C. salvatrix Swynn. \& Philipson and in Psilanthus travancorensis (Wight \& Arn.) J.-F. Leroy $(2 \mathrm{n}=22)$ by employing the conventional acetic orcein technique as well as by $\mathrm{C}$ - and NOR-banding aiming further comparative studies. Although $C$. canephora and $C$. dewevrei have already been studied and depict a C-band karyotype, they have also been included for further comparisons, since NOR-banding and some other morphometric data have not been obtained yet. However, there were observed some differences among the species regarding chromosomal morphometry. The karyotype formula obtained was $3 \mathrm{~m}+6 \mathrm{sm}+2 \mathrm{sm}^{\mathrm{s}}$ for $C$. salvatrix and P. travancorensis, $1 \mathrm{M}+2 \mathrm{~m}+6 \mathrm{sm}$ $+2 \mathrm{sm}^{\mathrm{s}}$ for C. kapakata and $2 \mathrm{M}+1 \mathrm{~m}+6 \mathrm{sm}+2 \mathrm{sm}^{\mathrm{s}}$ for C. racemosa. All species displayed a moderate karyotype asymmetry and according to Stebbins system, C. canephora, C. dewevrei, C. kapakata and C. racemosa were classified as $3 \mathrm{~B}$ while C. salvatrix and $P$. travancorensis were classified as 2A. Among the four indices used to assess karyotype asymmetry, Paszko AI index along with Stebbins were best suited to individualize the species. C-bands were preferentially situated at a pericentromeric/centromeric position. Two pairs of chromosomes, with secondary constriction and satellite segments, were observed in all the species following acetic orcein staining. $C$. racemosa and $C$. salvatrix showed NOR-band in both pairs, while only one chromosome pair carrying NOR-band was seen in C. canephora, C. dewevrei, C. kapakata and P. travancorensis. Data on chromosome morphometry, asymmetry indices and NOR-banding were suitable for the characterization of the species.
\end{abstract}

Keywords: C-banding, coffee, karyotype, mitotic chromosomes, NOR-banding, Rubiaceae

\section{Introduction}

The Rubiaceae is the fourth largest family of angiosperms encompassing more than 600 genera ranging from herbaceous species, as the small and climbing Manettia cordifolia, to tall trees as Genipa americana. Some members are important for the extraction of biochemical compounds used in the pharmaceutical industry; others are employed with the purpose of gardening or recreational area ornamentation. Besides its agricultural and economical relevance, the best known Rubiaceae genus is by far Coffea, mainly the species of $C$. arabica and $C$. canephora, which are of great economical importance for the beverage production. They have been cultivated throughout the tropical regions principally in Africa, Central and South America. Species such as $C$. dewevrei and $C$. racemosa, for instance, have been cultivated only for local consumption. Despite the importance of the genus, the classification of several species is still an unsolved issue, especially concerning the systematic position of the controvertible genus Psilanthus, a closest relative of Coffea. These conflicts have generated studies at the molecular level, aiming a better knowledge of Coffea-Psilanthus affinities. Recently, molecular studies developed by Davis et al. (2011) in more than 80 coffee species using data from sequences from internal transcribed spacer (ITS) of nuclear ribosomal DNA and from plastid DNA have allowed for advances in the knowledge of the species and their relationships, helping to solve several conflicting classification. The authors subsumed Psilanthus genus under the Coffea as firstly established by Chevalier (1947), increasing the number of species from 104 to 124 . The genus Coffea is composed by perennial trees or shrubs which may grow in regions from tropical evergreen forests to drier environments such as savannahs, showing different caffeine content ranging from a high one in some $C$. arabica and $C$. canephora varieties to a very low or null caffeine content in others as in C. salvatrix and C. pseudozanguebariae, for instance (Kumar et al., 2006; Santa Ram et al., 2005).

Chromosome research in coffee species has been done for a long time and begun with Faber (1910) in the megasporogenesis of wild C. liberica who had made an at- 
40

tempt to visualize and count the mitotic chromosomes of the ovules. Thenceforth, the studies developed in the genus of species ranged from the identification of the most probable genomes involved in the Arabica origin (Pinto-Maglio and Cruz, 1987), the establishment of the first karyogram and ideogram for $C$. arabica based on pachytene chromosomes (Pinto-Maglio and Cruz, 1998), following studies in several diploid species to determine the nuclear content (Cros et al., 1998), the heterochromatin localization and quantification in mitotic chromosomes (Pierozzi et al., 1999) and subsequently the heterochromatin molecular composition, as reviewed by Pinto-Maglio (2006) and Hamon et al. (2009). The first approaches in coffee chromosome studies however concerned the establishment of chromosome number which led to the finding that wild species are diploid $(2 n=22)$ while the Arabica varieties and cultivars are predominantly tetraploid $(2 n=44)$ with several hexaploid $(2 n=66)$ and octoploid $(2 n=88)$ exceptions (Krug, 1934, 1945).

Attempts to obtain karyotype or a median ideogram based on metaphase mitotic chromosomes were carried out by some authors who were unanimous in regards to chromosome small size which impaired its individualization in the genome (Bouharmont, 1963; Mendes, 1938). A comprehensive median ideogram however, with the localization of centromere and heterochromatin at chromosomes after orcein and C-banding, was obtained by Pierozzi $e t$ al. (1999) for C. canephora and C. dewevrei. Later, the characterization at cytomolecular level using fluorochromes and in situ hybridization with rDNA probes was performed by Lombello and Pinto-Maglio (2004 a, b, c) and afterwards by Hamon et al. (2009) in some coffee species which showed one to two pairs of chromosomes carrying rDNA sites. Despite these efforts, few diploid species have some chromosome morphometric information or an average ideogram based on mitotic chromosome measures with centromere, secondary constriction and satellite segment positioned (Pierozzi et al., 1999; Pierozzi and Silvarolla, 2011). Chromosome banding techniques have enabled the localization as well as the distribution pattern of heterochromatin (C-band) and nucleolar organizer sequences (NOR-band), which constitute reliable markers allowing for chromosome identification. So far, considering diploid species, a complete ideogram and C-bands have been obtained only for two species. In order to continue the characterization of mitotic chromosomes in the genus, other coffee diploid species and one species of Psilanthus have been analyzed by acetic orcein stain, C- and NOR banding (silver staining) aiming further comparative studies.

\section{Materials and methods}

Chromosome studies were performed on four diploid $(2 \mathrm{n}=22)$ auto-incompatible coffee species $C$. canephora, $C$. dewevrei (=C. liberica var. dewevrei), C. kapakata, $C$. racemosa, $C$. salvatrix and in one species of the genus $P$ si- lanthus, $P$. travancorensis $(2 \mathrm{n}=22)$. C. canephora and $C$. dewevrei had been studied and a median ideogram with $C$ band localization had already been published. These species belong to the IAC (Instituto Agronômico de Campinas) Coffee Collection where they were introduced and have been growing.

Seeds were placed to germinate on moist filter paper in Petri dishes at room temperature. Germinated roots were collected, treated for 3 hours in a saturated solution of p-DB (para-dichlorobenzene) at $16^{\circ} \mathrm{C}$, fixed in 3:1 (ethylic alcohol and acetic acid, respectively) solution and stored at $-20^{\circ} \mathrm{C}$. For cytological preparations, fixed root tips were softened in $20 \%(\mathrm{w} / \mathrm{v})$ pectinase (Roth art. 6839) and $2 \%$ (w/v) cellulase (Sigma art. C1184) mixture for 1 hour at $34^{\circ} \mathrm{C}$. It was applied: $(1)$ the conventional $1 \%$ acetic orcein technique (Sharma and Sharma, 1980) for the obtainment of chromosome measures; (2) adapted C-banding (Pierozzi et al., 1999) for heterochromatin visualization; and (3) NOR-banding (50\% $\mathrm{AgNO}_{3}$ aqueous solution and gelatin) as described in Howell and Black (1980) for location of nucleolar organizer regions (NOR).

The mean values for total chromosome length of haploid set (THCL), the average chromosome length per haploid set ( $\chi$ chrom), the absolute $(\mu \mathrm{m})$ and relative $(\%)$ chromosome length, the ratio $(\mathrm{L} / \mathrm{S})$ and the difference $(\mathrm{L}$ S) of the longest to the shortest chromosomes and the average centromeric index were calculated. The mean values for asymmetry index (AsI \%), according to Mugnier and Siljak-Yakovlev (1987), were also calculated. In addition to the AsI\% data, the karyotypes were also analyzed by (1) Stebbins' two-way system (Stebbins, 1958); (2) Romero Zarco (1986) intra (A1) and inter (A2) chromosomal system and (3) AI index as proposed by Paszko (2006) consisting of both coefficient of variation of chromosome length $(\mathrm{CVcl})$ and coefficient of variation of centromeric index ( $\mathrm{CVci})$. The chromosome data mean values were compared by F-test followed by Tukey-test. The species were grouped using clustering analyses based on Euclidean distances and it was drawn a simplified dendrogram showing the clusters obtained. It was employed 15 parameters for clustering analyses. A karyotype formulae and an average haploid ideogram was also obtained for each species. Chromosome measures and ideograms were based on ten metaphase cells. Chromosomes were identified and arranged based on their length and centromere position. Photomicrographies were taken by Olympus Vanox optical photomicroscope using Kodak film ASA 400.

\section{Results and discussion}

The morphometric data along with the asymmetry indices karyotype formula, NOR banding and ideograms were suitable in order to evidence some differences among the species studied (Fig. 1 to 3, Tab. 1 to 3).

C. salvatrix displayed the highest mean values for THCL, $\chi$ chrom, $S(\mu \mathrm{m})$ and S\%, however, the lowest val- 
Tab. 1. Mean values with standard deviation for total haploid chromosome length (THCL), average chromosome length $(\chi \mathrm{chrom})$, absolute mean values $(\mu \mathrm{m})$ for the longest $(\mathrm{L})$ and for the shortest chromosome (S), relative length of the longest $(\% \mathrm{~L})$ and the shortest $(\% \mathrm{~S})$ chromosome of Coffea canephora, C. dewevrei, C. kapakata, C. racemosa, C. salvatrix and $P$. travancorensis

\begin{tabular}{ccccccc}
\hline Species & THCL & $\chi$ chrom & $\mathrm{L}$ & $\mathrm{S}$ & $\% \mathrm{~L}$ & $\% \mathrm{~S}$ \\
\hline C. canephora & ${ }^{*} 16.97 \pm 0.95^{\mathrm{ab}}$ & $1.53 \pm 0.24^{\mathrm{bd}}$ & ${ }^{*} 2.38 \pm 0.07^{\mathrm{a}}$ & ${ }^{*} 0.85 \pm 0.03^{\mathrm{c}}$ & ${ }^{*} 14.00 \pm 0.23^{\mathrm{a}}$ & ${ }^{*} 5.03 \pm 0.19^{\mathrm{b}}$ \\
C. dewevrei & ${ }^{*} 15.60 \pm 1.11^{\mathrm{bc}}$ & $1.44 \pm 0.11^{\mathrm{bd}}$ & ${ }^{*} 2.03 \pm 0.06^{\mathrm{bc}}$ & ${ }^{*} 0.83 \pm 0.02^{\mathrm{c}}$ & ${ }^{*} 13.23 \pm 0.24^{\mathrm{b}}$ & ${ }^{*} 5.40 \pm 0.15^{\mathrm{c}}$ \\
C. kapakata & $17.88 \pm 1.46^{\mathrm{ab}}$ & $1.62 \pm 0.13^{\mathrm{ab}}$ & $2.38 \pm 0.29^{\mathrm{ab}}$ & $1.13 \pm 0.12^{\mathrm{ab}}$ & $13.32 \pm 1.12^{\mathrm{ad}}$ & $6.29 \pm 0.31^{\mathrm{a}}$ \\
C. racemosa & $14.51 \pm 1.10^{\mathrm{c}}$ & $1.32 \pm 0.10^{\mathrm{cd}}$ & $1.96 \pm 0.18^{\mathrm{bc}}$ & $0.79 \pm 0.11^{\mathrm{c}}$ & $13.66 \pm 0.37^{\mathrm{ab}}$ & $5.47 \pm 0.21^{\mathrm{c}}$ \\
C. salvatrix & $18.33 \pm 0.59^{\mathrm{a}}$ & $1.67 \pm 0.05^{\mathrm{a}}$ & $2.05 \pm 0.06^{\mathrm{bc}}$ & $1.24 \pm 0.09^{\mathrm{a}}$ & $11.20 \pm 0.32^{\mathrm{c}}$ & $6.77 \pm 0.46^{\mathrm{a}}$ \\
\hline P. travancorensis & $15.92 \pm 0.99^{\mathrm{bc}}$ & $1.45 \pm 0.09^{\mathrm{bc}}$ & $1.89 \pm 0.16^{\mathrm{c}}$ & $1.01 \pm 0.07^{\mathrm{b}}$ & $11.88 \pm 0.65^{\mathrm{cd}}$ & $6.35 \pm 0.42^{\mathrm{a}}$ \\
\hline
\end{tabular}

Means followed by the same letter $=$ differences were not significant at the level of $5 \%$ after Tukey test;

Means followed by different letters = differences were significant at the level of $5 \%$ after Tukey test;

* = data from Pierozzi et al. (1999) employed for comparisons

ues for $\mathrm{L} \%, \mathrm{~L} / \mathrm{S}$ and $\mathrm{L}-\mathrm{S}$. C. racemosa in contrast showed the lowest mean values for THCL, $\chi$ chrom, $S(\mu \mathrm{m})$ and $S \%$, however, the highest value for AsI\% (Tab. 1 to 3). All species examined showed two pairs of chromosomes with secondary constriction associated with a satellite segment in the long arm (Fig. 2). The satellite segment length for the chromosome 1 varied from $0.20 \mu \mathrm{m}$ in $C$. dewevrei to $0.40 \mu \mathrm{m}$ in C. kapakata and the length of the associated secondary constriction varied from $0.09 \mu \mathrm{m}$ in $P$. travancorensis to $0.11 \mu \mathrm{m}$ in the other species. The satellite segment length for the chromosome 3 varied from $0.16 \mu \mathrm{m}$ in $C$. canephora and in $C$. dewevrei to $0.27 \mu \mathrm{m}$ in $C$. racemosa and the length of the secondary constriction was $0.11 \mu \mathrm{m}$ in all the species studied except for $P$. travancorensis which was $0.28 \mu \mathrm{m}$ (Tab. 2).

Also, the size of the satellite segment and the secondary constriction enabled the recognition of at least two species, C. kapakata for the largest satellite segment on the chromosome 1 and $P$. travancorensis for the largest secondary constriction on the chromosome 3 (Fig. 2). Variations in the size of the secondary constriction and/or in the satellite segment have been reported as useful criteria for species recognition and have been of great relevance for interpreting karyo-evolutionary trends as observed in
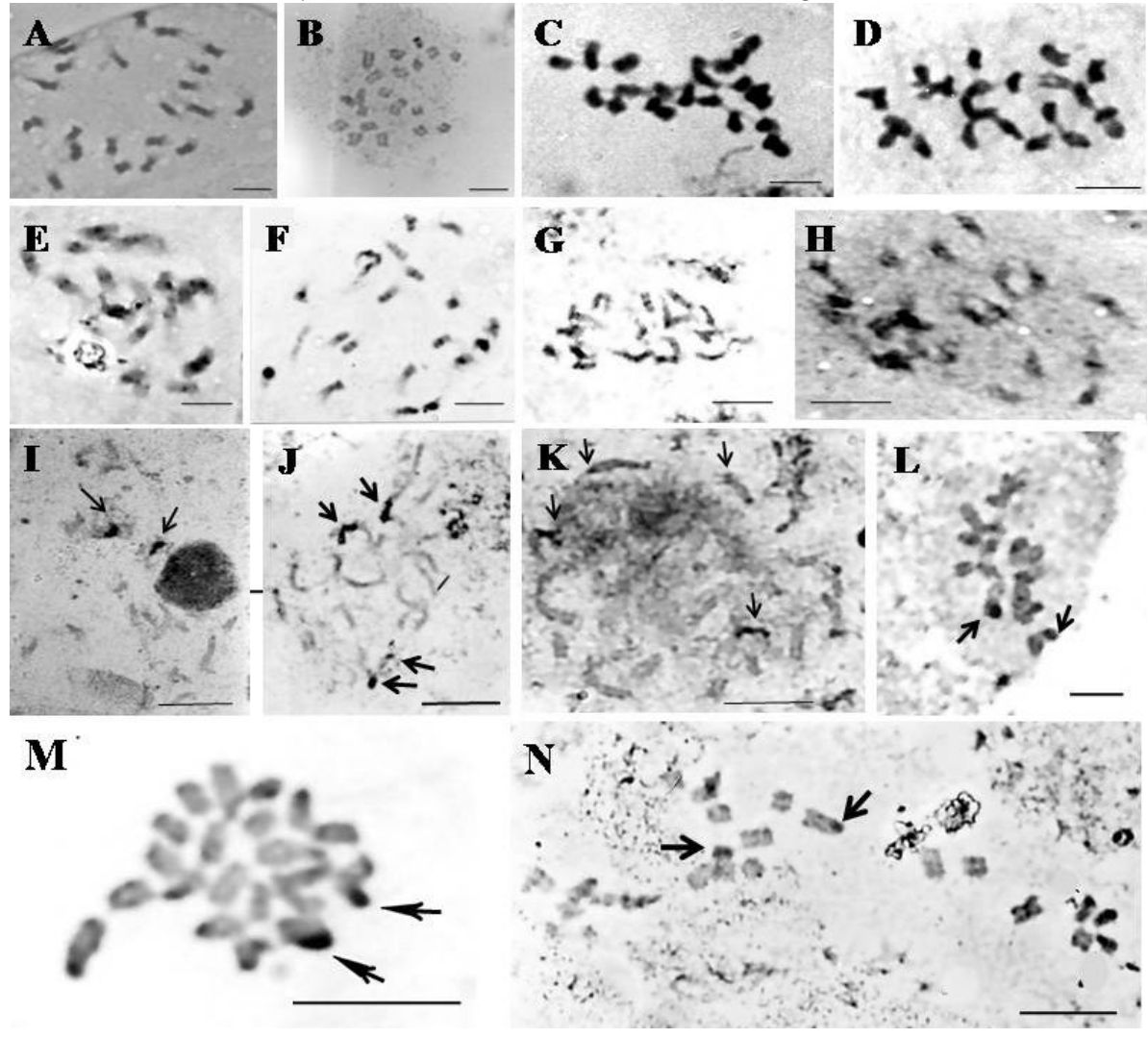

Fig. 1. Photomicrographies of mitotic chromosomes of C. kapakata (A, E, I), C. racemosa (B, F, J), C. salvatrix $(\mathrm{C}, \mathrm{G}, \mathrm{K})$ and $P$. travancorensis (D, H, L). after acetic orcein staining (A to D), C-banding (E to H) and NORbanding (I to L). C. canephora (M) and C. dewevrei (N) after NOR-banding Barr $=2 \mu \mathrm{m}$. Arrows $=$ NOR band 
Tab. 2. Mean values with standard deviation for the longest and the shortest chromosome ratio (L/S), the difference of the longest and the shortest chromosome (L-S), the karyotype formula, the number of NOR band (NOR), the length of satellite segment and secondary constriction anchored in chromosome $1\left(\mathrm{sat}^{1}\right.$ and $\left.\mathrm{sc}^{1}\right)$ and $3\left(\mathrm{sat}^{3}\right.$ and $\left.\mathrm{sc}^{3}\right)$ for Coffea canephora, C. dewevrei, C. kapakata, C. racemosa, C. salvatrix and P. travancorensis

\begin{tabular}{ccccccccc}
\hline Species & $\mathrm{L} / \mathrm{S}$ & $\mathrm{L}-\mathrm{S}$ & $\mathrm{KF}$ & $\mathrm{NOR}$ & $\mathrm{sat}^{1}$ & $\mathrm{sc}^{1}$ & $\mathrm{sat}^{3}$ & $\mathrm{sc}^{3}$ \\
\hline C. canephora & $2.82 \pm 0.39^{\mathrm{a}}$ & $1.53 \pm 0.22^{\mathrm{a}}$ & ${ }^{*} 1 \mathrm{M}+2 \mathrm{~m}+6 \mathrm{sm}+2 \mathrm{sm}^{\mathrm{s}}$ & 2 & 0.22 & 0.11 & 0.16 & 0.11 \\
C. dewevrei & $2.46 \pm 0.19^{\mathrm{ab}}$ & $1.18 \pm 0.15^{\mathrm{a}}$ & ${ }^{*} 3 \mathrm{~m}+6 \mathrm{sm}+2 \mathrm{sm}^{\mathrm{s}}$ & 2 & 0.20 & 0.11 & 0.16 & 0.11 \\
C. kapakata & $2.12 \pm 0.21^{\mathrm{bd}}$ & $1.26 \pm 0.22^{\mathrm{a}}$ & $1 \mathrm{M}+2 \mathrm{~m}+6 \mathrm{sm}+2 \mathrm{sm}^{\mathrm{s}}$ & 2 & 0.40 & 0.11 & 0.23 & 0.11 \\
C. racemosa & $2.53 \pm 0.37^{\mathrm{ab}}$ & $1.18 \pm 0.19^{\mathrm{ab}}$ & $2 \mathrm{M}+1 \mathrm{~m}+6 \mathrm{sm}+2 \mathrm{sm}^{\mathrm{s}}$ & 4 & 0.33 & 0.11 & 0.27 & 0.11 \\
C. salvatrix & $1.66 \pm 0.12^{\mathrm{d}}$ & $0.81 \pm 0.09^{\mathrm{c}}$ & $3 \mathrm{~m}+6 \mathrm{sm}+2 \mathrm{sm}^{\mathrm{s}}$ & 4 & 0.35 & 0.11 & 0.23 & 0.11 \\
\hline P. travancorensis & $1.86 \pm 0.15^{\mathrm{cd}}$ & $0.88 \pm 0.13^{\mathrm{bc}}$ & $3 \mathrm{~m}+6 \mathrm{sm}+2 \mathrm{sm}^{\mathrm{s}}$ & 2 & 0.27 & 0.09 & 0.21 & 0.28 \\
\hline
\end{tabular}

Means followed by the same letter $=$ differences were not significant at the level of $5 \%$ after Tukey test;

Means followed by different letters = differences were significant at the level of $5 \%$ after Tukey test;

${ }^{*}=$ data from Pierozzi et al. (1999) employed for comparisons

Capsicum species (Moscone et al., 1995) or as in some $V i$ cia species (Bisht et al., 1998), for instance.

No significant differences were seen among the species regarding centromeric index values. The karyotype formulae were $3 \mathrm{~m}+6 \mathrm{sm}+2 \mathrm{sm}^{\mathrm{s}}$ for $C$. salvatrix and $P$. travancorensis, $1 \mathrm{M}+2 \mathrm{~m}+6 \mathrm{sm}+2 \mathrm{sm}^{\mathrm{s}}$ for C. kapakata and $2 \mathrm{M}+1 \mathrm{~m}+6 \mathrm{sm}+2 \mathrm{sm}^{\mathrm{s}}$ for $C$. racemosa. The asymmetry in dex mean values (AsI \%) varied from $62.09 \pm 1.46(C$. kapakata) to $64.86 \pm 2.04$ (C. racemosa) and no significant difference was observed among the species analyzed (Tab. 3). C. salvatrix and P. travancorensis karyotypes were classified as $2 \mathrm{~A}$ while those of the remaining species as

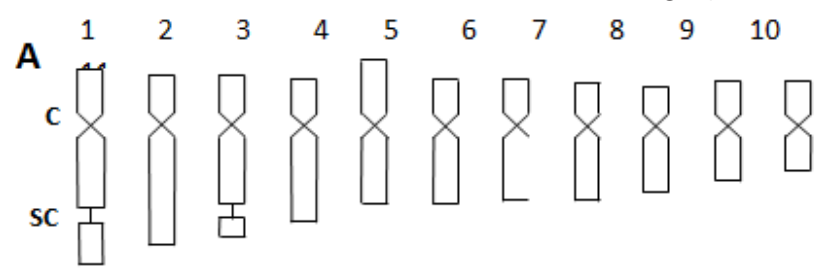

\section{B}

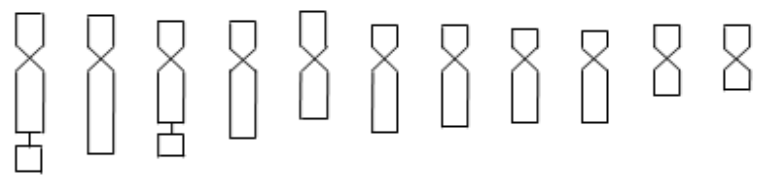

C

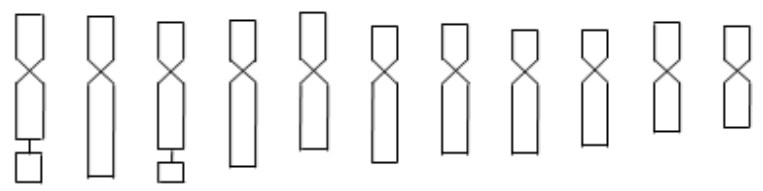

D

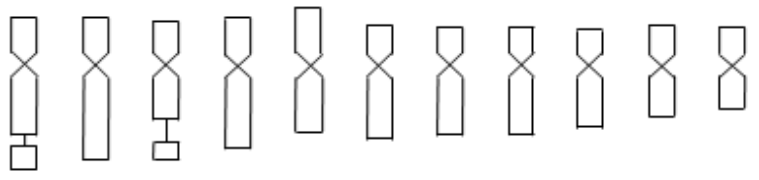

Fig. 2. Idiogram of haploid set of mitotic chromosomes of (A) Coffea kapakata, (B) C. racemosa, (C) C. salvatrix and (D) P. travancorensis. Bar $=2 \mu \mathrm{m}$
3B according to Stebbins concept. The highest values for components of Romero-Zarco and Paszko AI indices were observed in C. canephora for A1, in C. kapakata for A1 and A2, and in C. racemosa for A2 and AI. The lowest values for the same components were observed in C. salvatrix and $P$. travancorensis (Tab. 3).

The scattered diagram using $\mathrm{CVcl}$ and $\mathrm{CV}$ ci components from Paszko AI index not only showed a suitable separation of the species, but also allowed for an association with the Stebbins classification (Fig. 3). Even though the four indices pointed toward a moderate karyotype asymmetry, C. canephora, C. dewevrei, C. kapakata and $C$. racemosa displayed a more asymmetrical karyotype when compared with the other two, showing that this trend might be related to the ability of these species to explore the environments in a better way, in regards to the humid forest for the first three and the savannah for the last. Therefore, it is likely that small rearrangements in the chromosomes, privileging a better gene cluster, may have contributed to the karyotype asymmetry. According to Stebbins (1971), an increase in the karyotype asymmetry in angiosperms is associated to an increase in plant specialization and frequently related to evolutionary trends.

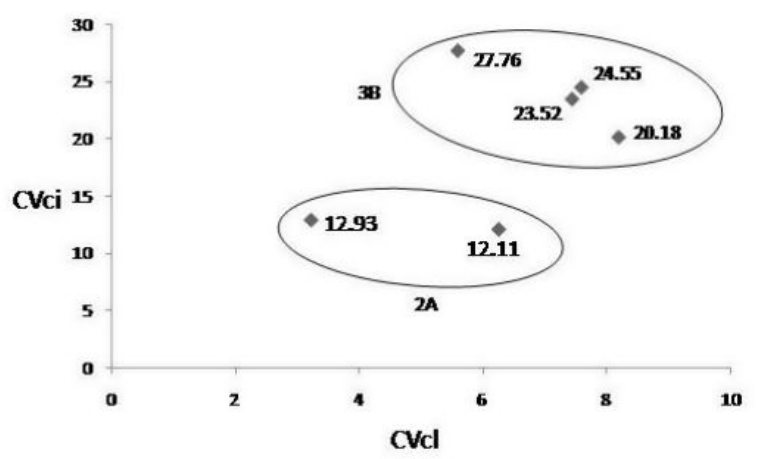

Fig. 3. Scattered diagrams showing karyotype asymmetry based on Paszko AI with $\mathrm{CVcl}$ and $\mathrm{CV}$ ci coefficients of variations for C. canephora (27.76), C. dewevrei (23.52), C. kapakata (20.18), C. racemosa (24.55), C. salvatrix (12.93) and $P$. travancorensis (12.11) and Stebbins' classification (2A and 3B) 
Tab. 3. Asymmetry indices values of Siljak and Yakovlev AsI\% (AsI\%), Stebbins (Stebb), A1 and A2 (Romero Zarco), and Paszko $\mathrm{CVcl}$ and $\mathrm{CV}$ ci components with the respective AI for Coffea canephora, C. dewevrei, C. kapakata, C. racemosa, C. salvatrix and P. travancorensis

\begin{tabular}{cccccccc}
\hline Species & AsI\% & Stebb & A1 & A2 & CVcl & CVci & AI \\
\hline C. canephora & ${ }^{*} 62.68 \pm 1.74^{\mathrm{a}}$ & 3B & 0.49 & 0.06 & 5.59 & 27.76 & 1.55 \\
C. dewevrei & ${ }^{*} 61.70 \pm 3.16^{\mathrm{a}}$ & 3B & 0.47 & 0.07 & 7.43 & 23.52 & 1.75 \\
C. kapakata & $62.09 \pm 2.18^{\mathrm{a}}$ & 3B & 0.49 & 0.08 & 8.18 & 20.18 & 1.65 \\
C. racemosa & $64.86 \pm 2.04^{\mathrm{a}}$ & 3B & 0.43 & 0.08 & 7.58 & 24.55 & 1,86 \\
C. salvatrix & $63.10 \pm 0.98^{\mathrm{a}}$ & 2A & 0.39 & 0.03 & 3.23 & 12.93 & 0.42 \\
P. travancorensis & $62.89 \pm 0.84^{\mathrm{a}}$ & 2A & 0.40 & 0.06 & 6.25 & 12.11 & 0.76 \\
\hline
\end{tabular}

Means followed by the same letter = differences were not significant at the level of $5 \%$ after Tukey test;

* = data from Pierozzi et al. (1999) employed for comparisons

In addition, C-banding was useful for demonstrating heterochromatin, despite the small size of coffee chromosomes, all species displayed a remarkable similar banding pattern resembling those obtained from C. canephora and C. dewevrei (Pierozzi et al., 1999) which presented only centromeric/pericentromeric bands and the absence of C-band in the satellite segment and/or in the secondary constriction of the coffee species studied (Fig. 1E to H).

Silver staining (NOR-banding) impregnation took place in chromosomal terminal/sub terminal positions (Fig. II to $1 \mathrm{~N}$ ). Although C. canephora, $C$. dewevrei, $C$. kapakata and $P$. travancorensis displayed two pairs of chromosomes carrying secondary constriction and a satellite segment (Fig. 2), only one pair was marked after silver impregnation, which presumably would be number three, as observed by Pierozzi et al. (1999) in C. canephora and in C. dewevrei. The presence of only one chromosome pair carrying nucleolar organizer region site in $C$. canephora, C. kapakata and P. travancorensis, has also been reported by Lombelo and Pinto-Maglio (2004 a, b) as well as in $C$. dewevrei by Hamon et al. (2009), with the in situ hybridization with $45 \mathrm{~S}$ rDNA probe. Conversely, C. racemosa and C. salvatrix showed silver impregnation (NOR band) in both chromosome pairs. Moreover, it is known that AgNOR positive impregnation actually reflects the location of rRNA genes (45S) which were active in the last mitotic interphase. Therefore, it is likely that the active NOR sites of chromosome pair one, might have been silenced in these four species, by some events such as: (I) a heavy cytosine methylation and/or by $\mathrm{H} 3$ histone modification; (2) a crucial inversion which hindered site transcription or impeded enzymes attach to $45 \mathrm{~S}$ genes promoter regions; (3) insertion of an alien DNA sequence which impaired the transcription; (4) DNA modification which impaired RNA pol I transcription machinery to remain associated with rDNA sites; (5) or by some other internal rearrangement during the process of adaptation to the environment, for instance, therefore, allowing for more accurate studies at molecular level. The existence of two pairs of chromosomes carrying NOR active sites in $C$. racemosa and $C$. salvatrix may possibly be related to the plant necessity to grow and to fructify in an environment with less availability of water resources, such as a drier biome as the savannah. Four sites of NOR bands were also observed by Pierozzi (personal communication) at the same chromo- some pairs in C. stenophylla, a species that occurs in a drier forest. C. racemosa and C. salvatrix apart from having four common active NOR sites, they also display some overlap in their Eastern African geographic distribution area. Moreover, data from Carvalho and Mônaco (1969) and Louarn (1982), showed that artificial crossing between these species resulted unproductive/fruitless, suggesting that lack of affinity might have arisen from a strong physiological/ecological barrier between them. In addition, the utilization of numeric taxonomy in some coffee showed that C. salvatrix was clustered far from the other ones, mainly from C. racemosa (Lopes et al., 1984). Ten coffee species and two of Psilanthus have already been analyzed so far, using chromosome morphometric data and/ or NOR banding (Pierozzi et al., 1999; Pierozzi and Silvarolla, 2011), and all of them displayed two pair of chromosomes with secondary constriction with the associated satellite segment visible after acetic orcein staining. It seems that initially, there were four active NOR sites (45S), i.e., two pairs of chromosomes carrying NOR region, in coffee species and this condition might have prevailed during the last arid period the African continent experienced. According to Anthony et al. (2010), coffee species might have survived to the drier climate in some West-African refuges. The presence of four active NOR regions could be interpreted as essential to survive in this drier biome with limited water resources and therefore could be also interpreted as a plesiomorphic character while the only one active pair of NOR could be an apomorphic character which may have arisen later by rRNA genes inactivation or silencing as a consequence of the occupation and adaptation to the forest, a more humid environment.

It is possible to observe in the dendrogram (Fig. 4) that there are a cluster composed by $P$. travancorensis and $C$. salvatrix and a cluster by $C$. dewevrei and $C$. racemosa. C. kapakata shares some affinity with the last two species, following C. canephora. The closeness of $P$. travancorensis to C. salvatrix observed through karyomorphometric data (Tab. 1 and 2), asymmetry indices (Tab. 3, Fig. 3) and dendrogram (Fig. 4) strengthen the observations made by some authors as Lashermes et al. (1997), Cros et al. (1998), Davis et al. (2007) and Maurin et al. (2007) for instance, using some non-coding sequences of nuclear (ITS) and chloroplast DNA. 


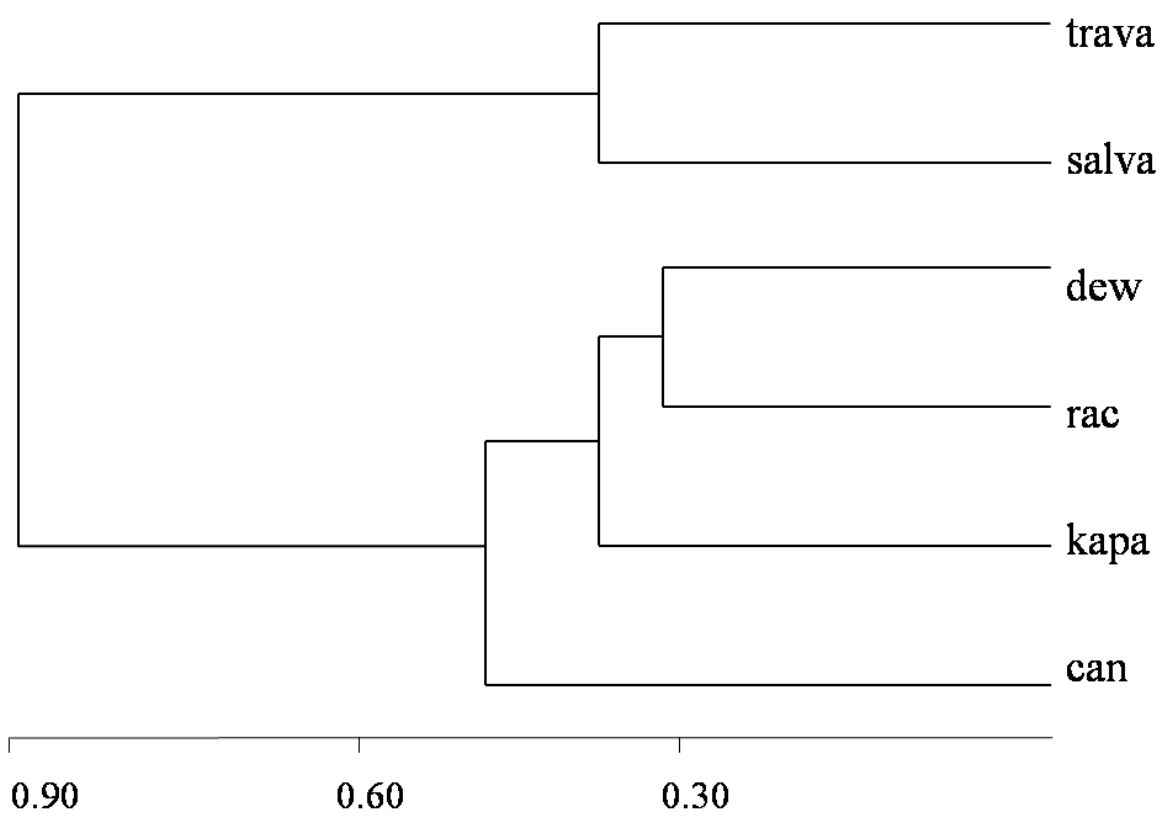

Fig. 4. Dendrogram based on Euclidean distance for the species studied: $C$. canephora (can), $C$. dewevrei (dew), C. kapakata (kapa), C. racemosa (rac), C. salvatrix (salva), P. travancorensis (trava)

The combination of morphological and molecular data have shown strong support for a very close relationship between Coffea and Psilanthus which lead to the conclusion that Psilanthus are not an independent lineage and both genera, in fact, are a single genus, i.e., Coffea, which has recently been redefined by Davis et al. (2011). Moreover, the phylogenetic study previously done by Lashermes et al. (1997) also nested P. travancorensis among coffee species; and fertile hybrids were obtained by crossing an artificial autotetraploid $(2 \mathrm{n}=44)$ P. ebracteolatus with C. arabica (Couturon et al., 1998). Based on molecular evidences Davis et al. (2011) suggested that the origin of Asian Psilanthus clade which includes $P$. travancorensis is on the African continent. In addition, $C$. salvatrix and $P$. travancorensis beans share the same characteristic, they are practically caffeine-free (Campa et al., 2005; Santa Ram et al., 2005). Recently, two Ty1-copia-like retrotransposons (Nana and Divo) were isolated from some coffee species and from P. ebracteolatus by Hamon et al. (2011), which strengthen the greater closeness of both genera.

The chromosomal studies performed on diploid coffee species and also in Psilanthus travancorensis were relevant since they contributed for a better species characterization through the morphometric data. They also pointed to a close relation between the Indian $P$. travancorensis to C. salvatrix, an East African species, supporting the first conclusion of Lashermes et al. (1997) as well as the recent Psilanthus-Coffea reclassification done by Davis et al. (2011). In addition, during the dispersion course through Africa the coffee species might have also experienced small chromosome structural changes and the silencing of localized segment via epigenetic mechanism, for instance. Based on the karyomorphometric and banding results ob- tained, it is likely the differences observed among species have appeared during plant speciation allowing them to explore different and new areas and small translocations, inversions, duplications, or other events that favored some better gene clusters may have well taken part in these processes.

\section{Conclusions}

The morphometric data along with asymmetry indices and NOR-band were suitable for species characterization and for demonstrating that the controvertible Psilanthus travancorensis showed many similarities with coffee species.

\section{Acknowledgments}

The authors wish to thank CNPq for PIBIC-IAC grant for T.C. Borghi during the training in IAC.

\section{References}

Anthony F, Diniz LEC, Combes MC, Lashermes P (2010). Adaptive radiation in Coffea subgenus Coffea L. (Rubiaceae) in Africa and Madagascar. Plant Syst Evo 285:51-64.

Bisht MS, Kesavacharyulu K, Raina SN (1998). Nucleolar chromosome variation and evolution in the genus Vicia. Caryologia 51:133-147.

Bouharmont J (1963). Somatic chromosomes of Coffea species. Euphytica 12:254-257.

Campa C, Doulbeau S, Dussert S, Hamon S, Noirot M (2005). Diversity in bean caffeine content among wild Coffea species: evidence of a discontinuous distribution. Food Chem 91:633-637. 
Carvalho A, Mônaco LC (1969). Genetic relationships of selected Coffea specie. Ciência e Cultura 19:151-165.

Chevalier A (1947). Les caféiers du Globe: III. Systematique des caféiers et faux-caféiers, maladies et insect nuisibles. Paul Lechevalier, Paris.

Couturon E, Lashermes P, Charrier A (1998). First intergeneric hybrids (Psilanthus ebracteolatus Hiern $\times$ Coffea arabica L.) in coffee trees. Can J Botany 76:542-546.

Cros J, Combes MC, Trouslot P, Anthony F, Hamon S, Charrier A, Lashermes P (1998). Phylogenetic analysis of chloroplast DNA variation in Coffea L. Mol Phylogenet Evol 9:109117.

Davis AP, Tosh J, Ruch N, Fay MF (2011). Growing coffee: Psilanthus (Rubiaceae) subsumed on the basis of molecular and morphological data; implications for the size, morphology, distribution and evolutionary history of Coffea. Bot J Linn Soc 167:357-377.

Faber FC (1910). A little about the biology of coffee flower. Teysmannia 21:559-577 (in German).

Hamon P, Siljak-Yakovlev S, Srisuwan S, Robin O, Poncet V, Hamon S, Kochko A (2009). Physical mapping of rDNA and heterochromatin in chromosomes of 16 Coffea species: a revised view of species differentiation. Chromosome Res 17:291-304.

Hamon P, Duroy P-O, Dubreil-Tranchant C, Costa PMA, Duret C, Razafinarivo NJ, Couturon E, Hamon S, Kochko A, Poncet V, Guyot R (2011). Two novel Ty1-copia retrotransposons isolated from coffee trees can effectively reveal evolutionary relationships in the Coffea genus (Rubiaceae). Mol Genet Genomics 285:447-460.

Howell WM, Black DA (1980). Controlled silver-staining of nucleolus organized regions with a protective colloidal developer: a 1-step method. Experientia 36:1014-1015.

Krug CA (1934). Contribution for cytology of the Coffea genus. Boletim Téchnico 11. Instituto Agronômico, Campinas (in Portuguese).

Krug CA (1945). Coffee improvement: twelve years 19331944 of basic and applied research done in Genetic, Coffee and Cytology departments of Instituto Agronômico. Superintendência dos Serviços do Café, São Paulo (in Portuguese).

Kumar V, Naidu MM, Ravishankar GA (2006). Development in coffee biotechnology - in vitro plant propagation and crop improvement. Plant Cell Tiss Org 87:49-65.

Lashermes P, Combes MC, Trouslot P, Charrier A (1997). Phylogenetic relationships of coffee-tree species (Coffea L.) as inferred from ITS sequences of nuclear ribosomal DNA. Theor Appl Genet 94:947-955.

Lombello RA, Pinto-Maglio CAF (2004 a). Heterochromatin and rDNA sites in Coffea L. chromosomes revealed by FISH and CMA/DAPI I: C. humilis, C. kapakata, C. sp. Moloundu and C. stenophylla. Caryologia 57:11-17.

Lombello RA, Pinto-Maglio CAF (2004 b). Heterochromatin and rDNA sites in Coffea L. chromosomes revealed by FISH and CMA/DAPI II: C. canephora cv. 'Apoatã', C. salvatrix, and C. sessiliflora. Caryologia 57:138-143.

Lombello RA, Pinto-Maglio CAF (2004 c). Cytogenetic studies in Coffea L. and Psilanthus Hook. using CMA/DAPI and FISH. Cytologia 89:85-91.

Lopes CR, Cunha RA, Blotta LF (1984). Taxonomic studies in Coffea genus with the aim of numerical methods. Turrialba 34:421-430 (in Portuguese).

Louarn J (1982). Evaluation of interspecific hybridization among African diploid coffee from Côte d'Ivoire collection. Proc Int Coffe Conf-ASIC 10:375-383 (in French).

Maurin O, Davis AP, Chester M, Mvungi EF, Jaufeerally-Fakim J, Fay MF (2007). Towards a phylogeny for Coffea (Rubiaceae): identifying well-supported lineages based on nuclear and plastid DNA sequences. Ann Bot 100:1565-1583.

Moscone EA, Loidl J, Ehrendorfer F, Hunziker AT (1995). Analysis of active nucleolus organizing regions in Capsicum (Solanaceae) by silver staining. Am J Bot 82:276-287.

Mendes AJT (1938). Morfologia dos cromossomos de Coffea excelsa Chev. Publicação 2610. Instituto Agronômico, Campinas (in Portuguese).

Mugnier C, Siljak-Yakovlev S (1987). Karyological study in some Yugoslavian populations of Hypochoeris (Compositae). Caryologia 40:319-325.

Paszko B (2006). A critical review and a new proposal of karyotype asymmetry indices. Plant Syst Evol 258:39-48.

Pierozzi NI, Pinto-Maglio CAF, Cruz ND (1999). Characterization of somatic chromosomes of two diploid species of Coffea L. with acetic orcein and C-band techniques. Caryologia 52:1-8.

Pierozzi NI, Silvarolla MB (2011). The use of chromosome morphometric data in a comparative study among diploid coffee species (Coffea L.) and Psilanthus bengalensis Hook. Cong Bras Genet 57:1.

Pinto-Maglio CAF (2006). Cytogenetics of coffee. Braz J Plant Physiol 18:37-44.

Pinto-Maglio CAF, Cruz ND (1987). Pachytene chromosome morphology in Coffea L. I. Nucleolar chromosomes. Caryologia 40:7-23.

Pinto-Maglio CAF, Cruz ND (1998). Pachytene chromosome morphology in Coffea L. II. C. arabica complement. Caryologia 51:19-35.

Romero Zarco C (1986). A new method for estimating karyotype asymmetry. Taxon 35:526-530.

Santa Ram A, Indu EP, Chandrashekar A, Ravishankar GA, Ganesh D (2005). Identification of low caffeine coffees in some interespecific hybrids and their progenies. J Plantation Crops 33:90-94.

Sharma AK, Sharma A (1980). Chromosome techniques. Butterworth and Co. Pub. Ltd., London.

Stebbins GL (1958). Longevity, habitat, and release of genetic variability in the higher plants. Cold Spring Harb Symp 23:365-378.

Stebbins GL (1971). Chromosomal Evolution in Higher Plants. Edward Arnold Pub. Ltd., London. 